\title{
ПРИНЦИПЫ ПОДГОТОВКИ К КОНКУРСАМ ПРОФЕССИОНАЛЬНОГО МАСТЕРСТВА СТУДЕНТОВ СПО
}

\author{
О. В. Ольховикова \\ Московский гуманитарный университет
}

Аннотация: В статье рассматриваются принципы подготовки студентов $к$ участию в конкурсах профессионального мастерства в системе среднего профессионального образования (СПО).

Ключевые слова: конкурс; профессиональное мастерство; WorldSkills; среднее профессиональное образование

\section{PRINCIPLES OF PREPARATION FOR PROFESSIONAL SKILL COMPETITIONS OF SPE PRINCIPLES OF PREPARATION FOR PROFESSIONAL SKILLS COMPETITIONS OF SVE STUDENTS}

\author{
O. V. Olkhovikova \\ Moscow University for the Humanities
}

Аннотация: The article describes the principles of preparation of students to participate in competitions of professional skills in the system of secondary vocational education (SVE).

Keywords: competition; professional skills, WorldSkills, secondary vocational education

Мы разделяем мнение Э. Р. Гайнеева в том, что в настоящее время основной задачей в подготовке выпускников СПО становится преодоление разрыва между требованиями производства и уровнем подготовки выпускника. Это обуславливается тем, что на протяжении довольно продолжительного периода времени система подготовки рабочих кадров в нашей стране была ориентирована не на развитие самостоятельности в поисках решений в нестандартных ситуациях, а на исполнение типовых технологических функций (Гайнеев, 2018: 3). Однако сегодняшние работодатели предъявляются повышенные требования к квалификации выпускников образовательных учреждений СПО: нужны нравственные, образованные, творческие люди, 
которые могут нестандартно смотреть на решение различного рода проблем, владеющие навыками исследовательской деятельности, и умеющие самостоятельно принимать решения (Астаева, 2017: 29). Подготовка кадров по наиболее востребованным и перспективным специальностям и рабочим профессиям, входящим во ФГОС ТОП-50, в соответствии с международными стандартами и передовыми технологиями должна осуществляться с учетом потребностей региональной экономики и приоритетами ее развития (Ольховикова, 2017: 183).

Для решения поставленных задач в системе среднего профессионального образования в настоящее время все более актуальным становится включение образовательного учреждения и его обучающихся в конкурсное движение, которое может быть рассмотрено как внеурочная деятельность учащихся, способствующая выполнению важных учебно-воспитательных задач, имеющая большое образовательное и воспитательное значение (Гайнеев, 2018: 3).

Конкурсы профессионального мастерства выступают не только как соревновательный элемент в системе подготовки выпускников СПО с целью выявить лучшего в своей профессии, но и служат стимулом к саморазвитию личности, являясь в то же время индикатором профессиональной компетентности учащихся и педагогов. Помимо этого, конкурсы профессионального мастерства могут являться достаточно объективным средством мониторинга общего состояния системы профессиональной подготовки квалифицированных рабочих кадров в системе СПО, а также отдельных направлений образовательного процесса, материально-технического оснащения образовательных учреждений.

Вступление в 2012 году России в международную некоммерческую организацию WorldSkills International (WSI) стало особенно значимым для развития и популяризации рабочих профессий и специальностей.

Основой подготовки к участию в конкурсах профессионального мастерства является активное внедрение в образовательный процесс компетентностного подхода, создание условий для формирования у обучающихся опыта самостоятельного решения познавательных, коммуникативных, организационных, нравственных и иных проблем (Астаева, 2017: 30).

Огромную роль в подготовке студента к конкурсам профессионального мастерства играет наставник - преподаватель, готовящий конкурсанта. Помимо обладания необходимыми компетенциями, знаниями, навыками, педагог должен уметь заинтересовать своим предметом студента, научить его, а также постоянно повышать свое педагогическое мастерство и квалификацию, активно принимать участия в профессиональных конкурсах, состоять в профессиональных сообществах. 
Отметим следующие принципы, которые могут быть использованы при подготовке к конкурсам профессионально мастерства:

Системность и непрерывность - подготовка к конкурсам должна начинаться с первого курса (или даже раньше) и продолжаться на протяжении всего периода обучения студента.

Максимальная самостоятельность - как в выполнении самих заданий, так и в принятии решений в различных возникающих ситуациях.

Активность знаний - все знания и навыки, полученные при подготовке к конкурсам активны (актуальны) и требуют постоянного их применения, расширения и углубления.

Принцип опережающего уровня сложности - задания для подготовки к конкурсам должны иметь повышенный уровень сложности.

Анализ результатов прошедших конкурсов - рефлексия.

Индивидуальный подход - учитываются как психологические особенности конкурсанта, так и его профессиональные качества.

Участие в конкурсе профессионального мастерства позволяет конкурсанту не только более детально вникнуть в будущую профессию, получить как теоретические знания, так и необходимые практические навыки, формирует творческую самостоятельность, правильную самооценку и самоопределение в профессиональной среде.

\section{СПИСОК ЛИТЕРАТУРЫ}

Астаева, С. С. (2017) Профессиональная адаптация студентов СПО в условиях студенческого самоуправления: дисс. ... магистра педагогики. Ишим.

Гайнеев, Э. Р. (2018) Дуальный подход в подготовке студентов к чемпионату профессий WorldSkills // Среднее профессиональное образование. № 10.

Ольховикова, О. В. (2017) Конкурсная деятельность как система повышения престижа рабочих профессий студентов СПО // Проблемы современного педагогического образования. Серия: Педагогика и психология. Ялта: РИО ГПА. Вып. 56. Ч. 1. С. 182-188.

Дата поступления: 20.12.2019 г.

Ольховикова Ольга Владимировна - аспирант кафедры педагогики и психологии высшей школы Московского гуманитарного университета. Адрес: 111395, Россия, г. Москва, ул. Юности, д. 5 . Тел.: +7 (903) 101-15-55. Эл. адрес: olgadlb65@gmail.com. Научный руководитель - д-р пед. н., профессор В. А. Ситаров. 
Olkhovikova Olga Vladimirovna, Postgraduate Student, Department of Pedagogy and Psychology of Higher School, Moscow University for the Humanities. Postal address: 5, Yunosti St., Moscow, Russian Federation, 111395. Tel.: +7 (903) 101-15-55. E-mail: olgadlb65@gmail.com. Scientific Advisor - V. A. Sitarov, Doctor of Pedagogy, Professor.

\section{Для цитирования:}

Ольховикова О. В. Принципы подготовки к конкурсам профессионального мастерства студентов СПО [Электронный ресурс] // Научные труды Московского гуманитарного университета. 2020. № 1. URL: http://journals.mosgu.ru/trudy/article/view/1121 (дата обращения: дд.мм.гг.). DOI: 10.17805/trudy.2020.1.2 